\title{
PEMANFAATAN GAS FLARE DENGAN PENDEKATAN GREEN PRODUCTIVITY DI PT.XY
}

\author{
Nukhe Andri Silviana ${ }^{1}$, A. Rahim Matondang ${ }^{2}$ dan Juliza Hidayati \\ ${ }^{1}$ Magister Teknik Industri, Universitas Sumatera Utara \\ ${ }^{2,3}$ Dosen Fakultas Teknik Program Studi Teknik Industri, Universitas Sumatera Utara, \\ Jl. Prof. T. Maas Kampus USU, Medan \\ Jl. Rangga Sentap-Dalong, Sukaharja, Ketapang, Kalimantan Barat \\ Email : dewikusuma57@yahoo.com \\ Email : a_rms2@yahoo.com \\ Email : rivaijuliza@gmail.com
}

\begin{abstract}
Abstrak. Perusahaan nasional yang bergerak dalam bidang migas menyelenggarkan kegiatan pada sektor hulu adalah PT.XY. Secara garis besar kegiatan operasi yang berlangsung meliputi pengeboran, eksplorasi, dan kegiatan produksi dengan hasil akhir yaitu minyak mentah yang disalurkan ke Pangkalan Susu untuk pengapalan. Dalam kegiatan produksi menghasilkan limbah gas sisa (flare) sebesar 0.58 mmscfd yang berasal dari $17.05 \%$ dari gas alam yang dihasilkan. Gas flare merupakan gas sisa yang selama ini dilakukan pembakaran melalui flare stack untuk menghindari gas beracun seperti $\mathrm{H}_{2} \mathrm{~S}$ dan $\mathrm{CO}$ yang berbahaya bagi kesehatan manusia dan lingkungan. Namun aktivitas pembakaran dapat menimbulkan isu pencemaran lingkungan. Melalui pendekatan Green Productivity yang digunakan dalam penelitian ini diharapkan usaha reduksi limbah yang dilakukan dapat berpengaruh terhadap perbaikan kondisi lingkungan sekaligus meningkatan produktivitas perusahaan. Pada penelitian ini, dilakukan identifikasi adanya permasalahan pada perusahaan yang berhubungan dengan jumlah limbah yang berlebih dan berpotensi untuk direduksi. Sebelumnya dilakukan pengukuran produktivitas perusahaan selanjutnya dirumuskan dan dipilih berdasarkan kelayakannya untuk diimplementasikan melalui analisis finansial, dan estimasi kontribusi alternatif terhadap tingkat produktivitas Hasil penelitian, didapatkan alternatif solusi untuk mengatasi permasalahan perusahaan dengan memanfaatkan kembali gas flare menjadi bahan bakar untuk mesin insinerator. Alternatif ini memberikan kontribusi terhadap peningkatan produktivitas penggunaan material sebesar $23.32 \%$, manusia $83.8 \%$, modal $10.13 \%$, dan waste menurun sebesar 99\%. Penerapan Green Productivity dan pemantauan rona lingkungan secara keseluruhan dapat membantu perusahaan memenuhi salah satu persyaratan ISO 14001.
\end{abstract}

Keywords: Limbah Gas Sisa (Flare), Green Productivity, Reduksi Limbah

\section{Pendahuluan}

Industri minyak dan gas bumi (migas) melakukan kegiatan eksplorasi, produksi, pengolahan, transportasi dan pemasaran. Dalam kegiatan ini dibagi menjadi dua yaitu kegiatan usaha hulu yang meliputi kegiatan eksplorasi dan produksi sedangkan kegiatan hilir meliputi pengolahan, transportasi dan pemasaran.

Berdasarkan kenyataan tersebut, Salah satu perusahaan nasional dalam bidang migas menyelenggarkan kegiatan pada sektor hulu adalah PT.XY. Secara garis besar kegiatan operasi yang berlangsung meliputi pengeboran, eksplorasi, dan kegiatan produksi dengan hasil akhir yaitu minyak mentah yang disalurkan ke Pangkalan Susu untuk pengapalan. Selama berproduksi, PT.XY menghasilkan beberapa limbah yaitu limbah cair, padat dan gas. Limbah cair berupa air, yang dilakukan proses treatment kembali untuk digunakan lagi ke semua stasiun, sedangkan limbah padat yang berupa lumpur dikirim ke cilacap untuk diolah kembali menjadi batako. Dari pengamatan di lapangan, untuk limbah gas berupa gas sisa (flare) yang dihasilkan dari proses produksi minyak dan bumi dan selama ini dilakukan pembakaran ke udara bebas.

Sementara itu, gas flare yang dihasilkan oleh PT. XY belum sepenuhnya termanfaatkan sebagai alternatif yang ramah lingkungan, hal ini dikarenakan gas flare hanya dibuang ke udara melalui pembakaran sehingga menghasilkan emisi karbondioksida sebesar 33.51633655 ton/hari atau dengan kata lain perusahaan rugi sebesar \pm 200 USD setiap kali pembakaran. Maka, dengan memperhatikan komposisi dan potensi gas yang dihasilkan oleh PT.XY, maka gas sisa (flare) dapat 
dimanfaatkan kembali menjadi alternatif yang ramah lingkungan dengan menggunakan metode Green productivity. Green productivity adalah strategi peningkatan produktivitas bisnis dan kinerja lingkungan secara bersamaan, untuk keseluruhan pembangunan sosial dan ekonomi. Pendekatan metode ini, diharapkan dapat mengevaluasi dan memberikan alternatif-alternatif solusi perbaikan untuk peningkatan produktivitas dan kinerja lingkungan (APO,2006).

\subsection{Rumusan Masalah}

Berdasarkan latar belakang masalah yang telah diuraikan sebelumnya diketahui bahwa limbah gas sisa (flare) yang dihasilkan dari kegiatan produksi PT.XY dapat direduksi menjadi alternatif yang ramah lingkungan. Dimana pembakaran yang terjadi yang dilakukan terus menerus akan mempengaruhi ekosistem dan lingkungan serta dianggap losses karena masih memiliki potensi untuk dimanfaatkan kembali, maka permasalahan yang akan dicari pemecahannya melalui penelitian ini adalah bagaimana mengurangi limbah gas sisa (flare) yang menimbulkan polusi terhadap lingkungan menjadi alternatif yang ramah lingkungan.

\subsection{Tujuan Penelitian}

Merujuk kepada rumusan masalah penelitian di atas maka tujuan penelitian ini bertujuan untuk memanfaatkan limbah gas sisa (flare) menjadi bernilai ekonomis dan ramah lingkungan dengan pendekatan green productivity.

\subsection{Batasan dan Asumsi}

Batasan yang digunakan dalam penelitian ini adalah Penelitian tidak mencakup perubahan teknologi selain yang diterapkan oleh perusahaan.dan alternatf yang diusulkan bukan merupakan produk. Sedangkan asumsi yang digunakan adalah tidak adanya penambahan sumur pada saat penelitian.

\section{Bahan dan Metodologi Penelitian}

\subsection{Landasan Teori}

\subsubsection{Green Productivity}

Green Productivity merupakan bagian dari program peningkatan produktivitas yang ramah lingkungan dalam menjawab isu global tentang pembangunan berkelanjutan (sustainable development). Green Productivity adalah salah satu konsep peningkatan produktivitas yang berorientasi kepada perlindungan lingkungan yang didasarkan atas keseimbangan antara peningkatan produktivitas dan pembangunan berkelanjutan.
Hubungan antara produktivitas dan lingkungan dapat dilihat pada Gambar 1.

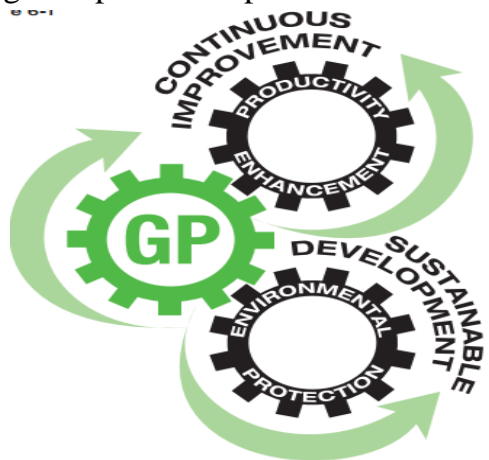

Gambar 1. Hubungan antara Produktivitas dan Lingkungan

Metodologi Green Productivity terdiri dari :

1. Getting Started

Melakukan pencarian informasi dengan melakukan work through survey. Pada tahapan ini dilakukan survey awal dengan menggunakan teknik wawancara.

2. Planning

Melakukan Identifikasi Masalah. Dalam identifikasi Masalah, diperlukan informasiinformasi mengenai bagian produksi dan informasi mengenai keadaan pabrik, kemudian penggunaan tools misalnya Diagram Ishikawa, Flow Process Chart, dan Material Balance.

3. Generation and Evaluation of Green Productivity Option

Berdasarkan identifikasi yang dilakukan, maka diperoleh masalah-masalah yang harus diperbaiki. Rumusan itu dikelompokkan dalam alternatif-alternatif untuk menyelesaikan masalah, masing-masing alternatif dihitung berdasarkan aspek produktivitas, lingkungan, dan sosial serta apakah alternatif tersebut layak untuk digunakan, untuk kemudian dapat dipilih alternatif mana yang akan dipilih. Berdasarkan pertimbangan-pertimbangan yang telah dilakukan, maka dipilih alternatif yang sesuai untuk dijadikan usulan untuk pengurangan gas flare di bagian produksi.

4. Implementation of Green Productivity Options

Sebelum alternatif benar-benar diimplementasikan, maka diperlukan langkah-langkah untuk mencapainya. Oleh karena itu, dalam tahap ini disusun hal-hal yang diperlukan untuk penerapan alternative. Pada tahap ini diperlukan berbagai usulan estimasi dari alternatif solusi yang diperoleh dari perhitungan.

5. Monitoring and Review

Dilakukan efektivitas pelaksanaan metode GreenProductivity dengan perhitungan IRR.

6. Sustaining Green Productivity

Pada tahap akhir ini dibentuk suatu system terstruktur untuk menjamin perbaikan 
produktivitas dan kinerja lingkungan secara terus-menerus dengan mengimplementasikan ISO 14001.

\subsubsection{Metodologi Penelitian}

Berikut ini adalah langkah-langkah metodologi penelitian yang dilakukan dalam penelitian ini pada Gambar 2. sebagai berikut :

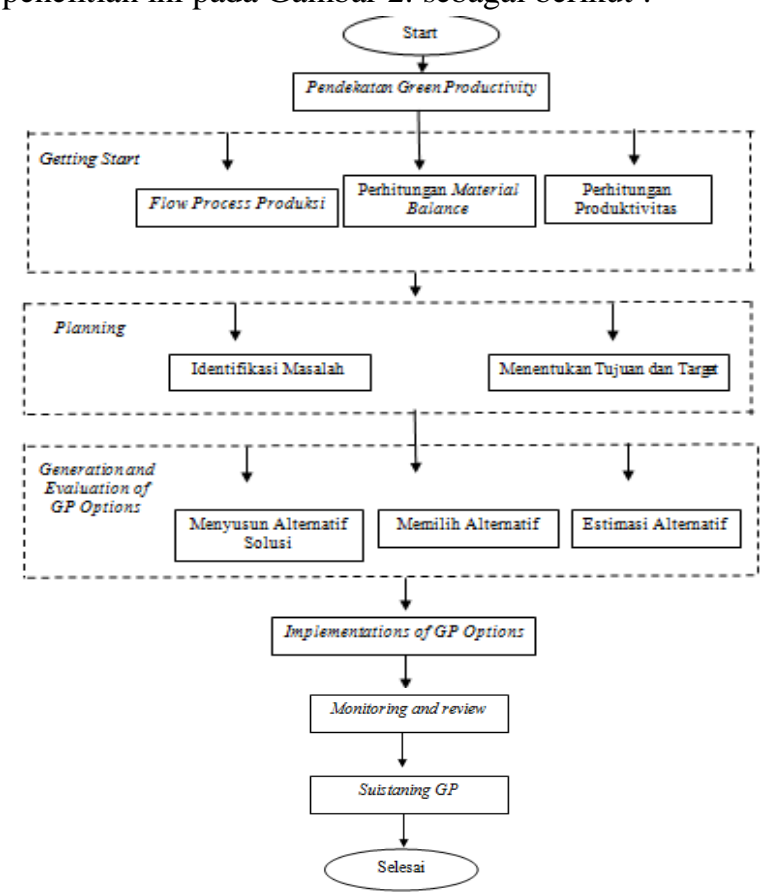

Gambar 2. Langkah - Langkah Penelitian

\section{Analisa dan Pembahasan}

3.1. Analisa

\subsubsection{Getting Started}

Tahap awal dalam penerapan green productivity yang merupakan proses pengumpulan data berbagai proses dasar dan proses identifikasi ruang lingkup permasalahan. Tools yang digunakan adalah sebagai berikut :

1. Flow chart digunakan untuk mengidentifikasi proses produksi mulai bahan jadi sampai siap untuk dipasarkan. Tahapan proses produksi minyak bumi dan gas dapat dlihat pada uraian dibawah ini:

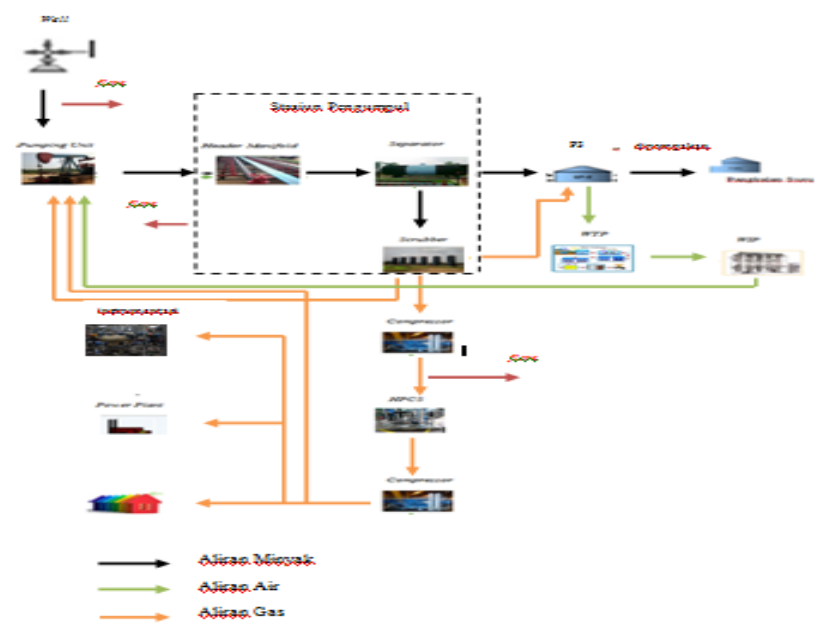

Gambar 3. Flow Chart Proses Produksi

2. Material Balance berfungsi untuk proses evaluasi kuantitatif terhadap material input dan output pada proses pengolahan minyak bumi dan gas. Misalnya produksi rata - rata perhari selama 5 tahun sebesar 3518,5 BPOD sedangkan produksi gas sebesar $4.7 \mathrm{mmscfd}$. 


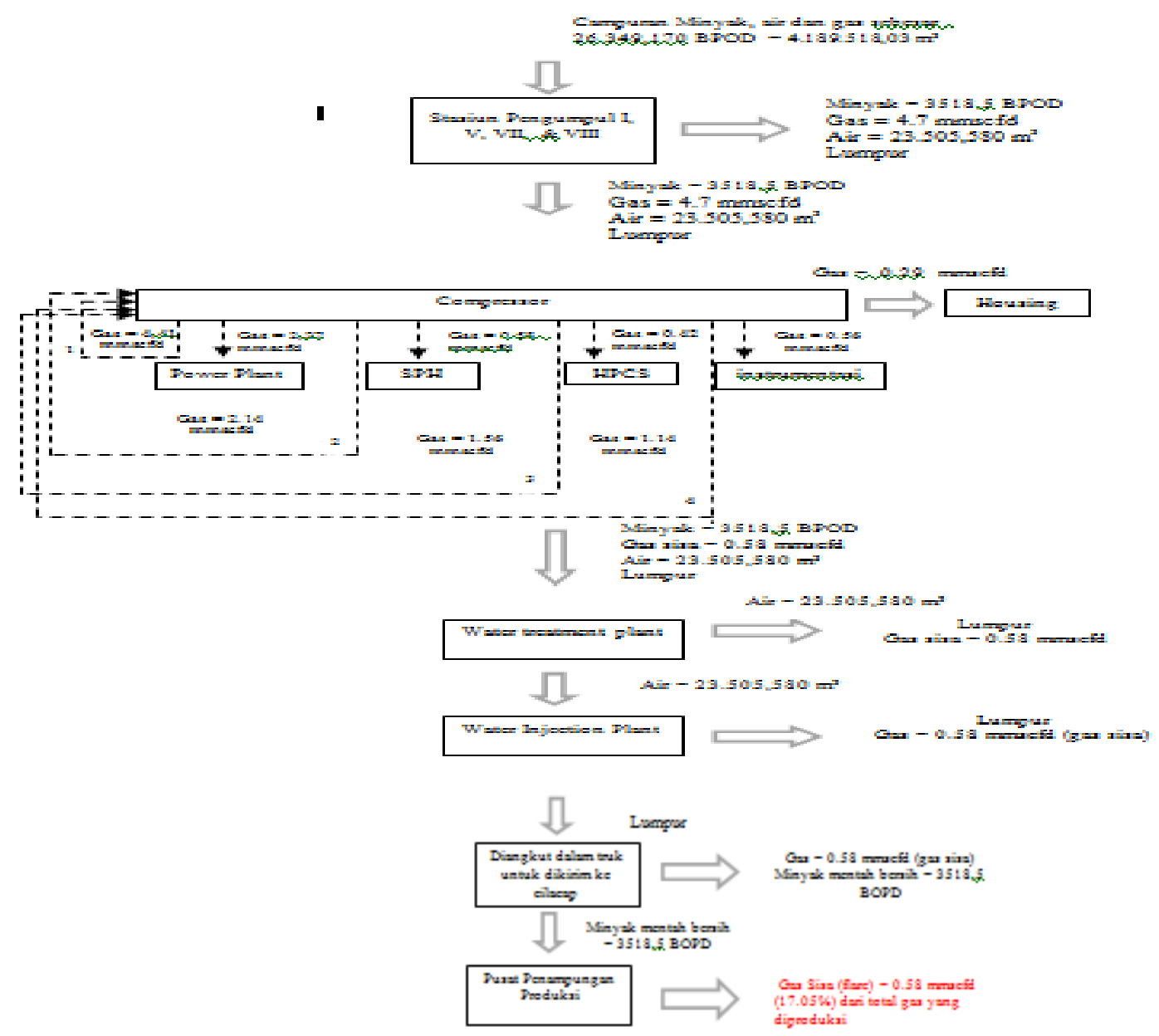

Gambar 4. Material Balance Proses Produksi Minyak dan Gas

3. Perhitungan Produktivitas

Nilai produktivitas bisa didapatkan dengan rumusan berikut ini :

$$
\mathrm{P}=\frac{\text { Output }}{\text { Input }} \times 100 \%
$$

Dengan menggunakan rumus tersebut maka hasil perhitungan nilai produktivitas perusahaan pada periode bulan Januari hingga Desember 2015 dapat dilihat pada tabel 1.

\section{Tabel 1. Nilai Produktivitas Tahun 2014 s/d} 2015

\begin{tabular}{|c|c|c|c|}
\hline No & Output & Input & Nilai Produktivitas \\
\hline 1 & $205,747,717,271$ & $21,000,000,000$ & 9.80 \\
\hline 2 & $169,787,953,986$ & $20,000,000,000$ & 8.49 \\
\hline 3 & $199,054,241,922$ & $21,000,000,000$ & 9.48 \\
\hline 4 & $198,573,141,583$ & $20,000,000,000$ & 9.93 \\
\hline 5 & $196,946,043,423$ & $20,000,000,000$ & 9.85 \\
\hline 6 & $184,674,553,282$ & $21,000,000,000$ & 8.79 \\
\hline 7 & $184,674,553,282$ & $21,000,000,000$ & 8.79 \\
\hline 8 & $216,490,801,574$ & $21,000,000,000$ & 10.31 \\
\hline 9 & $203,497,987,261$ & $20,000,000,000$ & 10.17 \\
\hline 10 & $210,054,974,493$ & $21,000,000,000$ & 10.00 \\
\hline 11 & $190,721,930,159$ & $21,000,000,000$ & 9.08 \\
\hline 12 & $196,146,206,445$ & $20,000,000,000$ & 9.81 \\
\hline 13 & $211,143,576,117$ & $21,000,000,000$ & 10.05 \\
\hline 14 & $195,350,549,141$ & $21,000,000,000$ & 9.30 \\
\hline 15 & $218,407,061,892$ & $21,000,000,000$ & 10.40 \\
\hline 16 & $199,365,193,290$ & $20,000,000,000$ & 9.97 \\
\hline 17 & $198,610,000,817$ & $21,000,000,000$ & 9.46 \\
\hline 18 & $178,311,804,649$ & $21,000,000,000$ & 8.49 \\
\hline
\end{tabular}

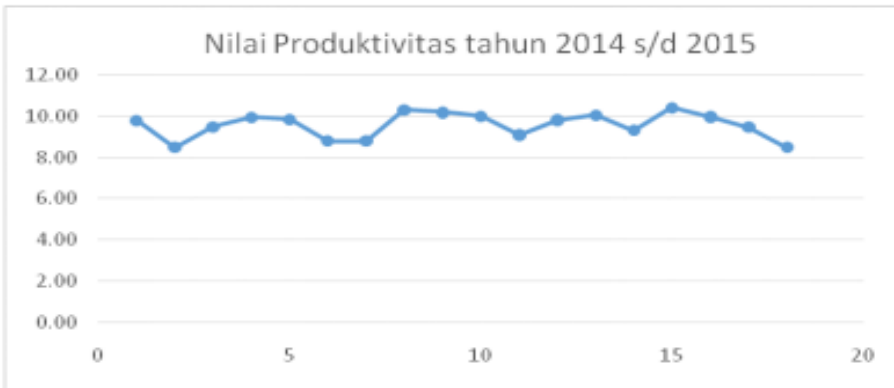

Gambar 5. Nilai Produktivitas Tahun 2014 s/d 2015

\subsubsection{Planning}

Pada tahap ini dilakukan upaya identifikasi masalah dan tujuan yang ingin dicapai dengan cara yaitu:

1. Identifikasi Masalah dilakukan dengan menggunakan diagram sebab akibat yang dapat dilihat pada Gambar 5. dibawah ini : 


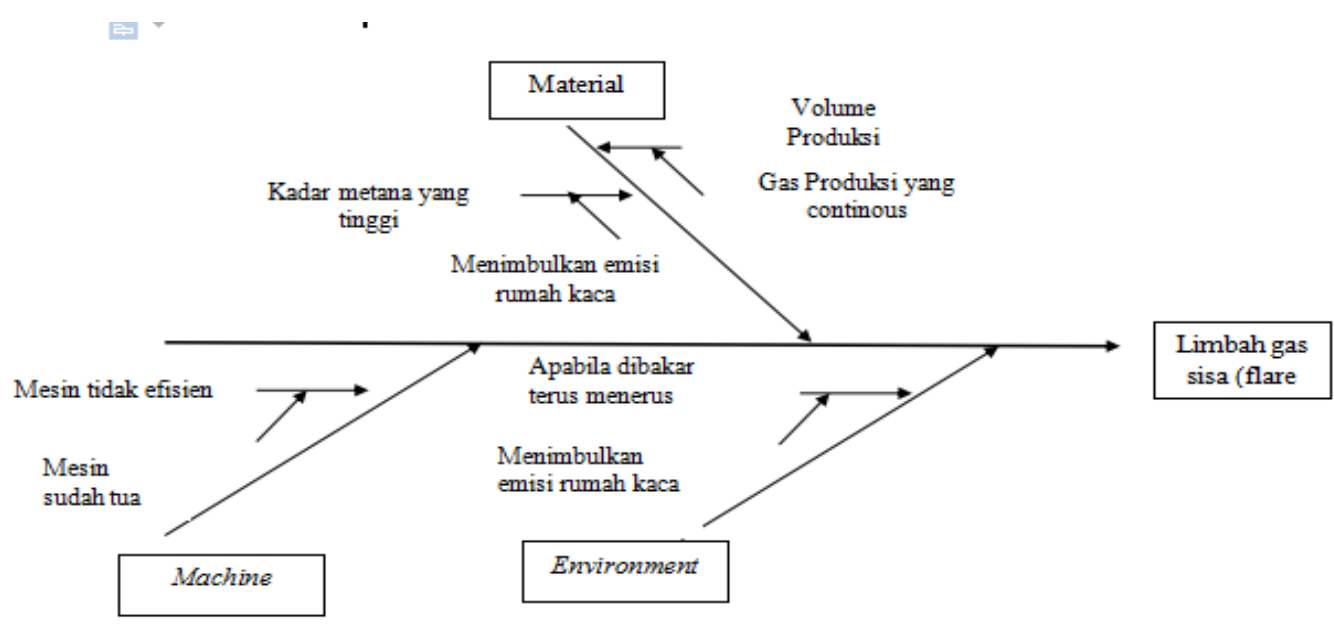

Gambar 6. Diagram Sebab Akibat

2. Penentuan dan Target yang ingin dicapai Berdasarkan identifikikasi masalah yang diuraikan melalui diagram sebab akibat tersebut adalah mereduksi limbah gas sisa (flare) yang berasal dari proses produksi menjadi alternative yang ramah lingkungan dengan tujuan untuk mencapai zero flaring 2030.

\subsubsection{Generation and Evaluation}

Dalam tahap generation and evaluation memiliki 2 langkah utama yaitu:

1. Penyusunan Alternatif

Penyusunan Alternatif yang diusulkan untuk mempertimbangkan aspek lingkungan, ekonomi dan social. Penyusunan alternatif ini digunakan untuk memanfaatkan limbah gas sisa menjadi alternatif ramah lingkungan mini lpg dan bahan bakar mesin incinerator.

2. Estimasi Kontribusi Alternatif dengan Tingkat Produktivitas
a. Alternatif I (Memanfaatkan Sebagai Mini LPG)
Pada Alternatif ini diperoleh Estimasi Biaya sebagai berikut :

Tabel 2. Estimasi Biaya Bulan Desember 2016

\begin{tabular}{lr}
\hline Keterangan & Estimasi Biaya/Bulan \\
\hline Output & $\mathbf{1 7 8 , 8 3 2 , 1 1 3 , 8 6 4}$ \\
Input & \\
Human & $\mathbf{2 , 2 7 0 , 1 9 9 , 8 5 6}$ \\
Material & $\mathbf{7 , 3 6 5 , 5 0 0 , 0 0 0}$ \\
Kapital/asset & $\mathbf{4 7 3 , 6 2 2 , 8 2 0 , 0 0 0}$ \\
\hline
\end{tabular}

b. Alternatif II (Memanfaatkan Gas Flare menjadi Bahan Bakar Mesin Incinerator)
Tabel 3. Estimasi Biaya Bulan Desember 2016

\begin{tabular}{lr}
\hline Keterangan & Estimasi Biaya/Bulan \\
\hline Output & $\mathbf{1 7 8 , 8 3 2 , 1 1 3 , 8 6 4}$ \\
Input & \\
Human & $\mathbf{2 , 1 0 8 , 7 9 9 , 8 5 6}$ \\
Material & $\mathbf{7 , 3 5 3 , 6 7 5 , 9 0 0}$ \\
Kapital/asset & $\mathbf{1 6 , 0 6 2 , 7 9 3 , 1 2 0}$ \\
\hline
\end{tabular}

3. Aspek Finansial

Aspek finansial merupakan salah satu alternative penyusunan dengan menggunakan metode deret seragam (annual worth). Data yang diperlukan meliputi biaya investasi, biaya operasional dan biaya penghematan.

a. Alternatif I (Memanfaatkan Sebagai Mini LPG)

Tabel 4. Rekap Biaya dan Penghematan untuk

\begin{tabular}{|c|c|c|}
\hline \multicolumn{2}{|l|}{ Jenis Biaya Penghematan } & Total Biaya/Tahun \\
\hline \multicolumn{3}{|l|}{ Investasi Awal } \\
\hline \multirow[t]{2}{*}{$\begin{array}{l}\text { Pembelian Peralatan Mini } \\
\text { LPG }\end{array}$} & & $197,341,800,000$ \\
\hline & & $2,368,101,600,000$ \\
\hline \multicolumn{3}{|l|}{ Biaya Operasional } \\
\hline \multicolumn{2}{|c|}{$\begin{array}{l}\text { Biaya Penambahan Tenaga } 27 \text { orang } \\
\text { Kerja }\end{array}$} & $186,000,000$ \\
\hline Pemeliharaan & $10 \%$ dari investasi & $\begin{array}{l}236,810,160,000 \\
\mathbf{2 3 6 , 9 9 6 , 1 6 0 , 0 0 0}\end{array}$ \\
\hline \multicolumn{3}{|l|}{ Penghematan } \\
\hline \multirow[t]{2}{*}{$99 \%$ waste digunakan } & 0.297 setara dengar & liter \\
\hline & $8411040 \times 3100$ & $\begin{array}{r}26,074,224,000 \\
312,890,688,000\end{array}$ \\
\hline
\end{tabular}

Pada Alternatif II, Analisis Benefit - cost diestimasikan 5 tahun mendatang. Hasil perhitungan dapat dilihat sebagai berikut :

I diasumsikan sebesar $18 \%$

Benefit : Penghematan (P/A.i\%.5)

$$
\begin{aligned}
& =\operatorname{Rp} 312,890,688,000 .(\mathrm{P} / \mathrm{A} .18 \% .5) \\
& =\operatorname{Rp} 312,890,688,000(3.12717) \\
& =\operatorname{Rp} 978,462,372,793
\end{aligned}
$$

Sedangkan Cost : Investasi Awal + Biaya

Operasional (P/A.i\%.5) 
$=\operatorname{Rp} 2,368,101,600,000+\operatorname{Rp} 236,996,160,000$

(P/A.18\%.5)

$=\operatorname{Rp} 2,368,101,600,000+\operatorname{Rp} 236,996,160,000$

(3.12717)

$=\operatorname{Rp} 8,146,583,562,139$

Maka : Indeks BCR untuk Alternatif II $=\frac{\text { Benefit }}{\text { cost }}$

$=\operatorname{Rp} 978,462,372,793 / \operatorname{Rp} 8,146,583,562,139$

$=0.12$

b. Alternatif II (Memanfaatkan Gas Flare menjadi Bahan Bakar Mesin Incinerator)

Tabel 5. Rekap Biaya dan Penghematan untuk Alternatif II

\begin{tabular}{llr}
\hline Jenis Biaya Penghematan & \multicolumn{2}{c}{ Total Biaya/Tahun } \\
\hline $\begin{array}{l}\text { Investasi Awal } \\
\begin{array}{l}\text { Pembelian Peralatan Mesin } \\
\text { Insinerator }\end{array}\end{array}$ & $182 \times$ Rp3.675.900 & $669,013,800$ \\
& & $\mathbf{8 , 0 2 8 , 1 6 5 , 6 0 0}$ \\
$\begin{array}{l}\text { Biaya Operasional } \\
\begin{array}{l}\text { Biaya Penambahan Tenaga } \\
\text { Keria }\end{array}\end{array}$ & 4 orang & $105,600,000$ \\
$\begin{array}{l}\text { Pemeliharaan } \\
\text { Biaya peralatan mesin } \\
\text { incinerator }\end{array}$ & $10 \%$ dari investasi & $9,633,798,720$ \\
& 3675900 & $44,110,800$ \\
Penghematan & & $9,783,509,520$ \\
$99 \%$ waste digunakan & 0.297 setara dengan 8.411 .040 liter \\
& $8411040 \times 3100$ & $26,074,224,000$ \\
& & $312,890,688,000$ \\
\hline
\end{tabular}

Sama halnya dengan Alternatif II, Analisis Benefit - cost pada alaternatif diestimasikan 5 tahun mendatang. Hasil perhitungan dapat dilihat sebagai berikut :I diasumsikan sebesar $18 \%$

Benefit : Penghematan (P/A.i\%.5)

$=\operatorname{Rp} 312,890,688,000 .(\mathrm{P} / \mathrm{A} .18 \% .5)$

$=\operatorname{Rp} 312,890,688,000$ ( 3.12717)

$=\operatorname{Rp} 978,462,372,793$

Sedangkan Cost : Investasi Awal + Biaya

Operasional (P/A.i\%.5)

$=\operatorname{Rp} 8,028,165,600+\operatorname{Rp} 9,783,509,520(\mathrm{P} / \mathrm{A} .18 \% .5)$

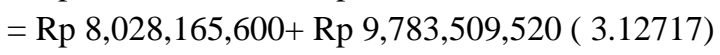

$=\operatorname{Rp} 55,700,136,085$

Maka : Indeks BCR untuk Alternatif III $=\frac{\text { Benef it }}{\text { cost }}$

$=\operatorname{Rp} 978,462,372,793 / \operatorname{Rp} 55,700,136,085$

$=17.56$

\section{Memilih Alternatif}

Yang menjadi pertimbangan dalam memilih alternatif perbaikan dilihat dari kontribusi untuk masing - masing alternatif. Sebagai contoh berapa besar kontribusi alternatif II untuk input human adalah :

Kontribusi $(\%)=24.13-85.16 / 85.16 \times 100 \%$

$$
=23.3 \%
$$

Hal yang sama dilakukan untuk setiap kontribusi pada masing - masing alternative yang dapat dilihat pada tabel 6 .
Tabel 6. Kontribusi Setiap Alternatif

\begin{tabular}{ccc}
\hline Pertimbangan & $\begin{array}{c}\text { Kontribusi } \\
\text { Alternatif } \\
\text { II (\%) }\end{array}$ & $\begin{array}{c}\text { Kontribusi } \\
\text { Alternatif III } \\
(\%)\end{array}$ \\
\hline Produktivitas & & \\
Material & 23.3 & 83.8 \\
Tenaga Kerja & 77.8 & 23.32 \\
Kapital & 0.6 & 10.13 \\
Waste & 0.1 & 0.11 \\
Emisi Karbon & 97.9 & 97.9 \\
Aspek Pendapatan & 1.08 & 1.00 \\
Masyarakat & 0.12 & 17.56 \\
Indeks BCR & & \\
\hline
\end{tabular}

Dari tabel 6. menunjukkan dari bahan pertimbangan kontribusi pada masing masing alternatif maka dipilih Alternatif III yang dapat diimplementasikan sebagai solusi perbaikan karena memiliki kontribusi besar dari setiap pertimbangan terhadap kinerja perusahaan dan kinerja lingkungan. Maka dengan mempertimbangkan beberapa aspek maka dipilih Alternatif III sebagai solusi pemecahan masalah bagi perusahaan.

\subsubsection{Implementation Of GP Options}

Setelah didapatkan alternatif solusi perbaikan yang memiliki kontribusi terbesar terhadap peningkatan produktivitas dan kinerja lingkungan, maka berikutnya dilakukan penyusunan rancangan implementasi dari alternatif yang telah terpilih tersebut yaitu alternatif II.

\subsubsection{Monitoring dan Review}

Setelah dilakukan implementasi terhadap usulan alternatif III, maka dilakukan monitoring and review dengan melakukan analisis IRR selama periode 5 tahun kedepan. Analisa Net Present Value (NPV) diestimasikan hingga periode 5 tahun kedepan, dimana hasil perhitungan NPV untuk alternatif yang terpilih yaitu Alternatif II adalah sebagai berikut :

Net Present Value $=$ PV Benefit - PV Cost

$=\operatorname{Rp} 978,462,372,793-\operatorname{Rp~55,700,136,085~}$

$=\operatorname{Rp} 922,762,236,708$

Kesimpulan : NPV untuk Alternatif III yang terpilih $>0$ maka alternative layak untuk dipertimbangkan implementasinya.

Sedangkan untuk Internal Rate Of Return (IRR) yang merupakan tingkat pengembalian dari suatu investasi dalam bentuk persentase. Perhitungan IRR 
ini digunakan untuk mencari tingkat bunga yang menghasilkan nilai annual (tahunan) dari suatu investasi sama dengan nol, sehingga untuk menghitung IRR berlaku persamaan seperti berikut ini :

$0=\mathrm{AW}_{(3)}-\mathrm{AW}_{(2)}$

Keterangan :

$\mathrm{AW}_{(2)}=$ Nilai annual worth dari Alternatif 2

$\mathrm{AW}_{(3)}=$ Nilai annual worth dari Alternatif 3

Maka,

$\mathrm{AW}_{(2)}=\mathrm{A}_{\text {benefit }}-\mathrm{A}_{\text {cost }}$

$=978,462,372,793-($ Biaya Investasi $(\mathrm{A} / \mathrm{P}, \mathrm{i} \%, \mathrm{n})+$

Biaya Operasional

$=978,462,372,793-(2,368,101,600,000$

$(\mathrm{A} / \mathrm{P}, \mathrm{i} \%, \mathrm{n})+236,996,160,000$

$=-2,368,101,600,000(\mathrm{~A} / \mathrm{P}, \mathrm{i} \%, \mathrm{n})+$

978,462,372,793 - 236,996,160,000

$=-2,368,101,600,000(\mathrm{~A} / \mathrm{P}, \mathrm{i} \%, \mathrm{n})+$

$741,466,212,793$

$\mathrm{AW}_{(3)}=\mathrm{A}_{\text {benefit }}-\mathrm{A}_{\text {cost }}$

$=978,462,372,793-($ Biaya Investasi $(A / P, i \%, n)+$

Biaya Operasional

$=978,462,372,793-(8,028,165,600(\mathrm{~A} / \mathrm{P}, \mathrm{i} \%, \mathrm{n})+$

$9,783,509,520$

$=-8,028,165,600(\mathrm{~A} / \mathrm{P}, \mathrm{i} \%, \mathrm{n})+978,462,372,793-$

$9,783,509,520$

$=-8,028,165,600(\mathrm{~A} / \mathrm{P}, \mathrm{i} \%, \mathrm{n})+968,678,863,273$

Perhitungan IRR $\left(\mathrm{i}^{*}{ }_{(3-2)}\right)$ dengan tingkat bunga

MARR $=18 \%$ adalah :

$0=\mathrm{AW}_{(3)}-\mathrm{AW}_{(2)}$

$0=(-8,028,165,600-(-2,368,101,600,000)$

$(\mathrm{A} / \mathrm{P}, \mathrm{i} \%, \mathrm{n}))+(968,678,863,273-$

$741,466,212,793)$

$0=2,360,073,434,400(\mathrm{~A} / \mathrm{P}, \mathrm{i} \%, \mathrm{n})$ -

$236,996,160,000$

$(\mathrm{A} / \mathrm{P}, \mathrm{i} \%, \mathrm{n})=\quad 236,996,160,000$

$=236,996,160,000(\mathrm{~A} / \mathrm{P}, 45 \%, 5)$

$=236,996,160,000(0,53318)$

$=126,361,612,589$

$(\mathrm{A} / \mathrm{P}, \mathrm{i} \%, \mathrm{n})$

$=2,360,073,434,400$

$=2,360,073,434,400(\mathrm{~A} / \mathrm{P}, 50 \%, 5)$

$=2,360,073,434,400(0.57583)$

$=1,359,001,085,731$

IRR $=\mathrm{i}_{2}+\frac{N P V_{2}}{\left(N P V_{2}-N P V_{s}\right)} \quad\left(\mathrm{i}_{2}-\mathrm{i}_{3}\right)$

$=45 \%+1,359,001,085,731 / 1,359,001,085,731$ -

$126,361,612,589 .(50 \%-45 \%)$

$\mathbf{= 4 5 , 0 5 \%}$

Kesimpulan :

Hasil Perhitungan IRR menunjukkan tingkat pengembalian perusahaan lebih besar dari MARR $18 \%$, maka alternatif III merupakan alternatif yang layak dipertimbangkan.

\subsubsection{Suistaining Green Productivity}

Green Productivity harus diintergrasikan menjadi bagian dalam manajemen harian. Tim Green Productivity harus membentuk sistem terstruktur untuk menjamin perbaikan yang terusmenerus dalam Green Productivity. Agar sistem tersebut berjalan dengan efektif, maka perlu terus memperbaharui kebijakan, target, tujuan dan prosedur saat diperlukan. Sisten tersebut dapat berupa penerapan International Organization For Standardization (ISO). Penerapan Green Engineering diharapkan dapat memenuhi salah satu persyaratan sertifikasi ISO 14001. Salah satu persyaratan untuk mendapatkan Sertifikasi ISO 14001 adalah bahwa perusahan sudah memantau keseluruhan aspek lingkungan.

\subsection{Pembahasan}

Berdasarkan pertimbangan yang diperoleh pada identifikasi masalah maka diberikan alternatifalternatif pemecahan masalah dimana alternatif I dimana fokus penyelesaian masalah tersebut dilakukan dengan pemanfaatan kembali gas flare menjadi mini LPG. Sedangkan alternatif II dengan memanfaatkan menjadi bahan bakar mesin incinerator.Dimana alternatif yaitu alternatif II dengan memanfaatkan gas flare menjadi bahan bakar menghasilkan penghematan sebesar 978,462,372,793 dan keuntungan 922,762,236,708.

\section{Kesimpulan dan Saran}

\subsection{Kesimpulan}

Alternatif yang terpilih untuk menurunkan jumlah gas sisa (flare) adalah alternatif III, digunakan sebagai bahan bakar pada mesin insinerator.

\subsection{Saran}

Beberapa saran yang dapat diberikan pada perusahaan untuk perbaikan di masa yang akan datang yaitu :

1. Upaya mereduksi gas sisa (flare) ini dapat dijadikan salah satu solusi implementasi green productivity pada perusahaan agar tercapai zero routine flaring yang dikeluarkan oleh world bank tahun 2030.

2. Penelitian selanjutnya perlu mengkaji lebih jumlah gas flare pada setiap sumur dan setiap stasiun pengumpul.

3. Penelitian selanjutkan perlu megkaji lebih dalam pemanfaatan gas flare dengan menggunakan pendekatan simulasi.

\section{DAFTAR PUSTAKA}

Asian Productivity Organization. 2006. Handbook on Green productivity. APO. Canada.

Abidin. Zainal. 2010. Analisis Potensi Penggunaan Bahan Bakar Gas untuk Sektor Transportasi di DKI Jakarta. Tesis. Universitas Indonesia. 
Ceria, dkk. 2012. Analisis Produktivitas Dan Environmental Performance Indicator (EPI) Pada produk SKM Dengan Metode Green Productivity Pada Perusahaan Rokok Adi Bungsu Malang. Universitas Brawijaya.

Ciptomulyono, 2011. Rancangan Sistem Informasi Pengukuran Green Productivity dan Environmental Management Accounting untuk Pengembangan Usaha Kecil Menengah. Prosiding Seminar Nasional Manajemen Teknologi XIII.

Courban, B., 2010, Flare gas and the role of $C N G$ a challenge and an opportunity, Paper presented at the 3rd Annual CNG/NGV Indonesia Forum 2010,Shangrila $29 \quad-30$ July 2010, Jakarta.

Dadang,Teknik Dasar Pengerjaan Logam, PPPPTK Boe Malang, 2013, hal.108-109

Indriani, G., 2005, Gas flaring reduction in the Indonesian oil and gas sector, technical and economic potential of clean developmentmechanism (CDM) project, HWWA Hamburg Report, Hamburg Institute of International Economics.

Kementerian Negara Lingkungan Hidup Republik Indonesia. 2009. Baku Mutu Emisi Gas Suar Bakar dalam Angka.

Kementrian Negara Lingkungan Hidup Republik Indonesia . 2014. Baku Mutu Air limbah dalam Angka

Kementrian Negara Lingkungan Hidup Republik Indonesia. 2012. Metodologi Penghitungan Tingkat Emisi Gas Rumah Kaca dalam rumus.

Lely, dkk. 2014. Peningkatan Produktivitas dan Kinerja IIngkungan Menggunakan Pendekatan Green productivity Pada Proses Produksi Pupuk Organik. Jurnal Rekayasa dana Manajemen Sistem Industri Vol.3 No.2. Universitas Brawijaya.
Mubin, dkk. 2012. Peningkatan Produktivitas dan Kinerja Lingkungan dengan Metode Green Productivity di PT. XYZ. Universitas Muhammadiyah Malang.

Made Suarsana. 2011. Global Warming: Ancaman Nyata Sektor Pertanian Dan Upaya Mengatasi Kadar $\mathrm{CO}_{2}$ Atmosfer.Widyatech Jurnal Sains dan Teknologi Vol. 11 No. 1 Agustus 2011. Hal. 31- 46.

Nofita, dkk. 2011. Peningkatan Produktivitas Melalui Usaha Waste Reduction dengan Pendekatan Green Productivity. (Studi Kasus: PT. Ecco Tannery Indonesia). Institut Teknologi sepuluh Nopember. Surabaya

Netty, dkk. 2015. Analisis Produktivitas Pada Proses Penyepuhan dengan Metode Green Productivity. Seminar Nasional IENACO. ISSN : 2337 - 4349. Institut Sains \& Teknologi AKPRIND Yogyakarta.

Santoso, dkk. 2015. Penerapan Green Productivity Untuk Peningkatan Produktivitas dan Kinerja Lingkungan Di Pabrik Gula Sragi. Seminar Nasional IENACO. ISSN : 2337 4349. Universitas Diponegoro.

Sasongko, 2008. Simulasi Pengelolaan Sampah Kota dengan Powersim. TEKNIK - Vol. 29 No. 2. ISSN 0852-1697. Hal : $96-103$

Singgih, Mosses L, 2012. Green Productivity : Konsep dan Aplikasi. Institut Teknologi sepuluh Nopember. Surabaya

Singgih, Moses L.2011. Implementasi Green Productivity Sebagai Upaya Untuk Meningkatkan Produktivitas dan Kinerja Lingkungan. Institut Teknologi sepuluh Nopember. Surabaya

Sinulingga Sukaria, 2014. Metode Penelitian. Edisi Ketiga. USU Press

Sinulingga. Sukaria, 2014. Rekayasa Produktivitas. USU Press. 